\title{
PRAWNA OCHRONA ZWIERZĄT \\ W REPUBLICE CZESKIEJ W PORÓWNANIU Z PRAWEM POLSKIM
}

\section{LEGAL PROTECTION OF ANIMALS \\ IN THE CZECH REPUBLIC IN COMPARISON WITH THE POLISH LAW}

http://dx.doi.org/10.12775/PPOS.2014.033

Artykuł recenzyjny: Hana Müllerova, Vojtěch Stejskal, Ochrana zviřat v pravu, Academia - Praha - 2013, s. 490

\section{STRESZCZENIE}

Celem tego szkicu jest przedstawienie - na tle czeskiego monograficznego opracowania prawnej ochrony zwierząt - kilku pod-

* Doktorantka na Wydziale Prawa i Administracji Uniwersytetu Śląskiego.

** Prof. dr hab., Instytut Nauk Prawnych PAN. 
stawowych cech czeskiego prawa ochrony zwierząt: historii regulacji, jej źródeł, miejsca w systemie prawa, statusu prawnego zwierząt, prawnych instrumentów ochrony, odpowiedzialności administracyjnej i karnej za znęcanie się nad zwierzętami, ochrony zwierząt w przepisach o ochronie przyrody, łowieckich i rybackich oraz skonfrontowanie ich z odpowiednikami w polskim prawie ochrony zwierząt.

\section{Słowa kluczowe}

Ochrona zwierząt; prawa zwierząt; znęcanie się nad zwierzętami; prawo ochrony przyrody; prawo łowieckie; prawo rybackie.

\section{ABSTRACT}

The aim of this paper is to present - on the background of the Czech monographic study of animals protection - some essential features of the Czech animal protection law: the history of animal protection law, its sources, its place in the legal system, the legal status of animals, legal protection instruments, administrative and penal responsibility for animal abuse, the protection of animals in the nature protection law, hunting law and fishing law as well as to confront them with their equivalents in the Polish animal protection law.

\section{Keywords}

Animal protection; animal rights; animal abuse; nature protection law; hunting law; fishing law.

W praskim wydawnictwie „Academia” ukazała się w 2013 r. monografia w pełni zasługująca na miano niezwykłej. Pod skromnym tytułem „Ochrona zwierząt w prawie” kryje się bogactwo treści filozoficznych, społecznych i prawnych przedstawionych na blisko pięciu setkach stron dużego formatu. Chcielibyśmy przybliżyć czytelnikowi polskiemu wyniki dociekań autorów, zwracając szczególną uwagę na obowiązujące prawo czeskie, które wielokrotnie nowelizowane przedstawia interesujący model uwzględniający w pełni wymagania tak prawa międzynarodowego, jak i unijnego. Chcielibyśmy także podjąć próbę porównania niektórych regulacji czeskich z polskimi, albowiem rozwiązania czeskie mogą stanowić pewną inspirację propozycji zmian w prawie polskim. 
Kilka słów o autorach. Dr Hana Müllerova z Instytutu Państwa i Prawa Czeskiej Akademii Nauk zajmuje się problematyką międzynarodowej ochrony środowiska ze szczególnym uwzględnieniem prawa jednostki do środowiska oraz możliwości jego realizacji, udziałem organizacji społecznych w ochronie środowiska, a także prawną ochroną zwierząt. Dr hab. Vojtěch Stejskal, docent w Katedrze Prawa Środowiska Uniwersytetu Karola w Pradze, jest uznanym czeskim autorytetem w dziedzinie prawnej ochrony przyrody i prawa karnego środowiska. Oboje są znani w Polsce, H. Müllerova z artykułów publikowanych w polskim czasopiśmie ${ }^{1}$, V. Stejskal z publikacji książkowych w Polsce recenzowanych' ; od początku (tj. od 2000 r.) uczestniczą także w dorocznych konferencjach polskich, czeskich i słowackich prawników zajmujących się ochroną środowiska.

Autorzy ujęli swe rozważania w czterech częściach:

I. Pozaprawne założenia ochrony zwierząt (s. 23-91);

II. Prawne założenia ochrony zwierząt (s. 93-150);

III. Ochrona zwierząt we współczesnych systemach prawnych (s. 151-265);

IV. Ochrona zwierząt w prawie Republiki Czeskiej (s. 267$-456)$.

Monografię kończą: prezentacja statystyczna doświadczeń na zwierzętach w Czechach (s. 459-465), pomysłowe zestawienie wymagań dobrostanu zwierząt w rolnictwie ekologicznym i tradycyjnym (s. 467-472), krótkie streszczenie angielskie (s. 473), imponująca bibliografia (s. 475-484) licząca 216 pozycji, w tym 67 anglojęzycznych, 27 niemieckojęzycznych i 16 w innych obcych dla autorów językach (wśród nich

1 H. Müllerova, Ochrona środowiska a Europejski Trybunał Praw Człowieka, „Ochrona Środowiska. Prawo i Polityka” 2010, Nr 1 oraz Niebezpieczne zwierzęta: ochrona zwierząt i ochrona człowieka przed nimi w czeskiej regulacji prawnej, „Ochrona Środowiska Prawo i Polityka” 2011, Nr 1.

2 Dwie najważniejsze to V. Stejskal, Uvod do pravni upravy ochrany prirody a peče o biologickou rozmanitost, Praha 2006 - artykuł recenzyjny W. Radeckiego w „Biuletynie Parków Krajobrazowych Wielkopolski” z. 13 z 2007 r. oraz Vyvojowe tendence pravni upravy ochrany prirody - artykuł recenzyjny W. Radeckiego w „Biuletynie Parków Krajobrazowych Wielkopolski” z. 19 z 2013 r. 
8 pozycji polskich), wykaz źródeł internetowych (s. 485) oraz wzorcowo sporządzony indeks (s. 487-490).

W mającej charakter wprowadzenia części I autorzy dokonują przeglądu idei religijnych i filozoficznych poświęconych relacji człowieka do zwierzęcia, podkreślając zwłaszcza pogłębienie antycznego i żydowskiego antropocentrycznego podejścia i rozwój etyki uprawniającej człowieka do dowolnego czy wręcz aroganckiego podejścia do przyrody. Przechodząc następnie przez buddyzm i hinduizm, kończą celną uwagą o dość podstawowym rozdziale między „zachodnim” i „wschodnim” myśleniu o zwierzętach. Podczas gdy na Wschodzie obserwujemy szacunek dla zwierząt, a nawet mistyczne kontemplacje, na Zachodzie przeważa idea pełnego panowania człowieka nad przyrodą.

Przegląd myśli filozoficznej rozpoczynają autorzy od Arystotelesowskiej idei hierarchicznego uporządkowania przyrody i poprzez poglądy stoików i autorów chrześcijańskich prowadzą czytelnika do Kartezjańskiego racjonalizmu, według którego zwierzęta nie mają duszy, świadomości, myśli ani uczuć, a zatem nie mogą też cierpieć. Zaczątki przełamywania takiego podejścia widzą autorzy w poglądach Jeremiego Benthama zaliczającego interesy zwierząt do interesów moralnych. Od niego zaczyna się stopniowy odwrót od czysto antropocentrycznego podejścia, pojawiają się zalążki myśli, że zwierzęta powinny być chronione dla nich samych. Naukowe wnioski Karola Darwina, akcent położony nie tyle na różnice, ile na podobieństwo między organizmami, był jednym z impulsów powstania zupełnie nowej ideologii postępowania człowieka ze zwierzętami i rozwoju legislacji ochronnej. Z idei współczesnych autorzy poddają analizie teorię równego traktowania interesów (ludzkich i zwierzęcych) Petera Singera, teorię szacunku dla życia Alberta Schweizera, teorię wewnętrznej wartości jednostki (człowieka i co najmniej ptaka i ssaka) Toma Regana.

Po przeglądzie zasadniczych problemów współczesności $\mathrm{w}$ relacjach między człowiekiem a zwierzęciem, do których zaliczają m.in. wielkie fermy hodowlane i ich konsekwencje, doświadczenia na zwierzętach, używanie zwierząt do tak czy 3/2014 inaczej rozumianej zabawy (ciekawe jest spojrzenie autorów na 
myślistwo, niekiedy uznawane za przeżytek, z którym należy skończyć; ich zdaniem ma ono jeszcze uzasadnienie, ale można sobie wyobrazić przyszłe ograniczenia myślistwa przez rozszerzanie zakazu polowań na kolejne gatunki zwierząt, zaostrzanie warunków polowania, wyłączanie niektórych terenów z gospodarki łowieckiej), chów zwierząt jako domowych pupilków, ochronę gatunków i ogrody zoologiczne, handel zagrożonymi gatunkami zwierząt - następuje niezwykle interesujące podsumowanie. Autorzy wskazują, że rozwój cywilizacji i zmiany sposobu życia wniosły do postępowania z niektórymi kategoriami zwierząt dalekosiężne zmiany. Zwłaszcza w drugiej połowie XX wieku rozwój doprowadził do niezrównoważonego stosunku do zwierząt (przede wszystkim gospodarskich i doświadczalnych), przesuwając je do kategorii rzeczy potrzebnych do egzystencji człowieka. Jednocześnie stosunek do zwierząt chowanych dla zaspokojenia zainteresowań osobistych ${ }^{3}$ oraz zwierząt dziko żyjących osiągnął poziom niespotykany nigdy w historii, podczas gdy zwierzęta gospodarskie i doświadczalne (laboratoryjne) tracą swą indywidualność. Dzisiejsze czasy charakteryzowane są pewnym paradoksem, wręcz hipokryzją: z jednej strony bardzo pozytywnym stosunkiem do zwierząt „członków rodziny" i adoracją zwierząt swobodnie żyjących w dziczy, z drugiej zaś stosunkiem do zwierząt hodowanych na skalę przemysłową dla produktów, których człowiek potrzebuje, albo dla rozwoju medycyny i wiedzy; losy tych zwierząt są dla większości społeczeństwa zgoła obojętne. Spostrzeżenie to prowadzi autorów do wniosku, że „piętą Achillesową” współczesnego stosunku człowieka do zwierząt jest sposób hodowli zwierząt gospodarskich i postępowania z nimi na wielkich fermach. Do tego dochodzą kolejne problemy, spośród nich najbardziej palące to doświadczenia na zwierzętach i wykorzystywanie zwierząt dla zabawy,

3 Dość trudny do zgrabnego przełożenia czeski termin zajmowy chov, jeśli zważyć, że zajem to „interes” bądź „zainteresowanie”. Najczęściej chodzi o zwierzęta trzymane w domu w charakterze towarzyszy (śliczny czeski termin mazliček, tj. „pieszczoszek”, odnoszony zwykle do psów i kotów, a może lepiej piesków i kotków), ale także choćby rybki akwariowe, kanarki, chomiki itp. 
w tym modne dążenia do rozszerzenia chowu motywowanego zainteresowaniami i tresowania przedstawicieli gatunków dziko żyjących, w tym chronionych. Właśnie krytyka warunków życia zwierząt gospodarskich, warunków nierespektujących ich biologicznych potrzeb zdaje się najwyraźniejszym motywem działań zmierzających do ochrony zwierząt i ich dobrostanu ${ }^{4}$. Zwiększenie zainteresowania licznych grup ludzi warunkami życiowymi zwierząt jest prymarnie reakcją na niezadowalającą sytuację w hodowli zwierząt gospodarskich. Zapewnienie ochrony zwierząt jest więc obecnie nadzwyczaj aktualną kwestią spośród tych najpilniejszych, można ją określić mianem jednego z kluczowych problemów naszej kultury w ogóle.

Autorzy wprowadzają dystynkcje pojęciowe polegające na tym, że terminem nadrzędnym jest ochrona zwierząt, które składa się z dwóch komponentów:

- negatywnego, oznaczającego ochronę zwierząt w znaczeniu węższym - przed dręczeniem ${ }^{5}$,

- pozytywnego, wyrażającego się w zapewnieniu zwierzętom dobrych warunków życiowych - welfare.

$\mathrm{Na}$ tle różnych spotykanych $\mathrm{w}$ literaturze klasyfikacji welfare autorzy akcentują, że pojęcie to wiąże się przede wszystkim z hodowlą zwierząt gospodarskich, a pojęcie dobrych warunków życiowych obejmuje aspekty nie tylko fizyczne, lecz także mentalne.

Druga część dzieła jest poświęcona założeniom prawnym. Początek prawnej ochrony zwierząt autorzy datują na XIX wiek, wcześniej pewnych elementów ochronnych dopatrują się w sferze moralności i religii. Przypominają stanowisko prawa rzymskiego ujmującego zwierzęta konsekwentnie w kategoriach rze-

4 Autorzy dzieła z pełną konsekwencją posługują się angielskim terminem welfare, który można oddawać w języku czeskim jako pohoda, w języku polskim jako „dobrostan”, ale wyraz welfare jest tak powszechnie przyjęty, że przekład jest zbędny.

5 Czeski termin tyrani wywodzony od tyranizovat, oddawany w języku polskim przez „tyranizować, dręczyć, maltretować”. Polskim odpowiednikiem prawnym i prawniczym jest „znęcanie się”, ale ze względów językowych preferujemy „dręczenie”, już choćby dlatego, aby przełożyć czeskie utyrani przez „zadręczenie”, którego przekład byłby przy „znęcaniu się” niemożliwy. 
czy. Pierwszą falę ustawodawstwa ochronnego widzą w Wielkiej Brytanii na przełomie XVIII i XIX wieku i wiążą ją z nazwiskiem Richarda Martina, który w 1822 r. doprowadził do przyjęcia przez parlament brytyjski ustawy o postępowaniu z końmi i bydłem. W latach 1822-1826 jako członek parlamentu przedłożył on kolejne sześć projektów ustaw dotyczących ochrony zwierząt, ale żaden z nich nie został przyjęty. Druga fala legislacji brytyjskiej zaczęła się w 1849 r. nowelą ustawy z 1822 r. i doprowadziła do uchwalenia w 1876 r. ustawy o ochronie zwierząt przed dręczeniem, która zakładała karalność doświadczeń na żywych zwierzętach, chyba że chodziło o jakieś szczególne względy naukowe. Kolejna brytyjska ustawa o ochronie zwierząt z 1911 r. obowiązywała aż do 2006 r. Podsumowując ten wstępny okres, autorzy akcentują przejście od pierwotnej idei ochrony zwierząt przed (wąsko ujętym) dręczeniem ze względu na porządek publiczny, przez ochronę samych zwierząt przed cierpieniem, do dążenia do zapewnienia zwierzętom dobrych warunków życia. Ich zdaniem kwestią kluczową na przełomie XX i XXI wieku jest rosnąca krytyka antropocentryzmu jako tradycyjnego poglądu na świat widzącego w człowieku wierzchołek stworzenia i władcę nad innymi formami życia, która to krytyka prowadzi do ekocentryzmu odrzucającego wyjątkowe położenie człowieka w całościowym ekosystemie Ziemi i jeszcze wyraźniej do biocentryzmu zakładającego pełnoprawność wszystkich form życia.

W rozważaniach nad prawnym statusem zwierząt autorzy dają wyraz przekonaniu, że prawdopodobnie nie ma powrotu do ujęcia zwierząt w kategorii rzeczy w znaczeniu prawa rzymskiego, a przyszły rozwój będzie zmierzał w kierunku wyboru jednej z trzech koncepcji:

- dalszym wzmacnianiem prawnej ochrony zwierząt nadal jako przedmiotów prawa, lecz z pozycją uprzywilejowaną w stosunku do przedmiotów nieżywych,

- przesunięciem zwierząt z kategorii przedmiotów prawa do podmiotów, z jednoczesnym wyposażeniem ich w prawa,

- wytworzeniem całkiem nowej kategorii, specjalnie dla zwierząt. 
Analizując różnorodne ruchy dążące do przyznania zwierzętom praw podobnych do ludzkich, autorzy opowiadają się przeciwko przyznaniu ich zwierzętom i uważają, że moralne prawa zwierząt (ale nie prawa podmiotowe) można na gruncie obowiązującego stanu prawnego wywodzić z odpowiednich powinności człowieka wobec zwierząt. Kończą uwagą, że przy przenoszeniu filozoficznych idei praw zwierząt do sfery prawa pozytywnego dotychczas nie udało się znaleźć wspólnego języka filozofów i prawników.

W trzeciej części autorzy analizują dzisiejszy stan prawny w trzech płaszczyznach: międzynarodowej, unijnej i krajowej. W prawie międzynarodowym akcentują Powszechną Deklarację Praw Zwierząt z 1978 r., towarzyszące jej dokumenty, system konwencji Rady Europy o różnych aspektach ochrony zwierząt, Światową Kartę Przyrody z 1982 r., a także trzy najważniejsze konwencje: waszyngtońską z 1973 r. o międzynarodowym handlu zagrożonymi gatunkami roślin i zwierząt (CITES), berneńską z 1979 r. o ochronie europejskiej fauny i flory oraz siedlisk przyrodniczych, a także przyjętą na Szczycie Ziemi w Rio de Janeiro w 1992 r. konwencję o ochronie różnorodności biologicznej. W prawie unijnym przedstawiają kolejno Deklarację o ochronie zwierząt i troski o nie dołączoną do Traktatu z Maastricht z 1992 r., protokół o ochronie i dobrych warunkach życiowych zwierząt, dołączony w 1999 r. do Traktatu Amsterdamskiego, wreszcie art. 13 Traktatu o funkcjonowaniu Unii Europejskie $\mathrm{w}$ brzmieniu Traktatu z Lizbony nakazujący pełne uwzględnianie wymagań w zakresie dobrostanu zwierząt przy formułowaniu i wykonywaniu różnych polityk unijnych. Zwracają uwagą na rozporządzenia unijne, m.in. o ochronie zwierząt w czasie transportu, obie dyrektywy przyrodnicze, tj. ptasią i siedliskową, unijne rozporządzenie wdrażające Konwencję CITES. W warstwie krajowej wskazują na zasadnicze cechy regulacji prawnej ochrony zwierząt jedenastu państw: Słowacji, Polski, Niemiec, Szwajcarii, Włoch, Austrii, Węgier, Norwegii, Danii, Wielkiej Brytanii i USA.

Po tych trzech częściach, opracowanych z godną podziwu starannością i precyzją, przy pełnym wykorzystaniu literatury 3/2014 światowej, następuje najobszerniejsza czwarta część dzieła, któ- 
rej przedmiotem jest prawo czeskie. Poświęcimy jej nieco więcej uwagi, konfrontując niektóre wybrane (na wszystkie nie ma, rzecz jasna, miejsca) regulacje czeskie z polskimi.

Zaczynają od scharakteryzowania systemu prawa ochrony zwierząt. Już we wstępie dają wyraz przekonaniu, że rosnące zainteresowanie problematyką ochrony zwierząt, w tym ochrony środkami prawnymi, doprowadzi do postrzegania zbioru norm prawnych regulujących tę ochronę jako samodzielnie traktowanej i będącej przedmiotem dydaktycznym „podgałęzi” prawa $^{6}$, mianowicie prawa ochrony zwierząt, wykładanego nie tylko w uczelniach rolniczych, lecz także na wydziałach prawa. Zdaniem autorów ciężar regulacji ochrony zwierząt spoczywa na prawie publicznym, znaczenie środków prawa prywatnego oferowanych przez kodeks cywilny jest ograniczone. W Republice Czeskiej zwierzęta nie są podmiotami prawa (nie mogą same domagać się swoich praw), lecz tylko przedmiotami stosunków prawnych. Źródła prawa ochrony zwierząt autorzy dzielą na trzy podstawowe grupy:

1) akty skierowane bezpośrednio na ochronę zwierząt, takim aktem jest podstawowa ustawa z 1992 r. o ochronie zwierząt przed dręczeniem ${ }^{7}$,

2) akty pośrednio skierowane na ochronę zwierząt, do których zaliczają zwłaszcza:

a) ustawę weterynaryjną z $1999 \mathrm{r}^{8}{ }^{8}$,

b) ustawę o hodowli zarodowej z 2000 r. ${ }^{9}$,

6 W oryginale: podobor prava; przy czym czeski wyraz obor jest wieloznaczny: 1. „specjalność, dziedzina, gałąź, branża”, 2. „kierunek studiów”, 3. „zakres”. W innym miejscu autorzy posługują się terminem pododvětvi, a czeskie odvětvi to słownikowo „gałąź, branża, dziedzina”, ale w naukach prawnych zawsze „gałąź”.

7 Zakon č. 246/1992 Sb., na ochranu zviřat proti tyrani. Czytelnikowi polskiemu należy się wyjaśnienie, jak powołuje się czeskie akty prawne. Czeski zakon to polska „ustawa”. Po literze „č (skrót od čislo, tj. numer) następuje pozycja, pod którą w oficjalnym zbiorze aktów prawnych Sbirka zakonů akt został opublikowany, łamana przez rok pierwszej publikacji (niezależnie od ewentualnych późniejszych tekstów jednolitych) i zakończona literami „Sb.”, tj. skrótowcem oficjalnego zbioru aktów prawnych.

8 Zakon č. 166/1999 Sb., veterinarni zakon.

9 Zakon č. 154/2000 Sb., plemenařsky zakon. 
3) mające swoistą pozycję fragmenty innych aktów, spośród których najważniejsze to:

a) ustawa z 1992 r. o ochronie przyrody i krajobrazu ${ }^{10}$,

b) ustawa z 2003 r. o ogrodach zoologicznych ${ }^{11}$,

c) ustawa łowiecka z $2001 \mathrm{r}^{12}$,

d) ustawa rybacka z 2004 r. $^{13}$

Na tym jednak nie koniec, ponieważ dla ochrony zwierząt istotne są także liczne dalsze akty prawne, których przedmiotem są m.in. rolnictwo ekologiczne, pasze, zdrowie publiczne, handel zagrożonymi gatunkami, a także przepisy procedury administracyjnej, kodeksów karnego i cywilnego, ustawy o wykroczeniach.

Ustawodawca polski prawne wymagania dotyczące ochrony zwierząt również zamieścił wielu aktach normatywnych. Prawo ochrony środowiska ${ }^{14} \mathrm{w}$ art. 127-128 określa jedynie ogólne zasady ochrony zwierząt, odsyłając (w art. 81 p.o.ś.) do przepisów szczególnych. Podstawową regulację $\mathrm{w}$ tym zakresie stanowi ustawa z dnia 21 sierpnia 1997 roku o ochronie zwierzą ${ }^{15}$, zgodnie z którą „zwierzę, jako istota żyjąca, zdolna do odczuwania cierpienia, nie jest rzeczą ${ }^{16}$. Człowiek jest mu winien poszanowanie, ochronę i opiekę" (art. 1 ust. 1 u.o.z.), jednakże „w sprawach nieuregulowanych w ustawie do zwierząt stosuje się odpowiednio przepisy dotyczące rzeczy" (art. 1 ust. 2 u.o.z.). P. Kozłowska i M. Szwarczyk zauważają, iż „zwierzęta zatem pozostają nadal $\mathrm{w}$ obrocie prawnym przedmiotami prawa, jednakże przedmiotami wyjątkowymi, dla których obowiązuje szczególny reżim prawny, wynikający z obowiąz-

10 Zakon č. 114/1992 Sb., o ochraně přirody a krajiny.

11 Zakon č. 162/2003 Sb., o zoologickych zahradach.

12 Zakon č. 449/2001 Sb., o myslivosti.

13 Zakon č. 99/2004 Sb., o rybařstvi.

14 Ustawa z dnia 27 kwietnia 2001 r., Prawo ochrony środowiska, tj. Dz. U. z 2013 r., poz. 1232 ze zm. (dalej: p.o.ś.).

15 Ustawa z dnia 21 sierpnia 1997 r., o ochronie zwierząt, tj. Dz. U. z 2014 r., poz. 856 (dalej: u.o.z.)

16 Zob. J. Stelmasiak, Komentarz do ustawy z dnia 21 sierpnia 1997 r. o ochronie zwierząt, [w:] Kompetencje po reformie administracji publicznej, pod red. Z. Niewiadomskiego, Warszawa 2000, s. 452-454. 
ków człowieka wobec nich w zakresie poszanowania i opieki"17. Przepisy odnoszące się do ochrony zwierząt znajdują się także między innymi: w ustawie z 16 kwietnia 2004 roku o ochronie przyrody $^{18}$, w ustawie z dnia 18 kwietnia 1985 r. o rybactwie śródlądowym ${ }^{19}$ oraz w ustawie z dnia 13 października 1995 r. Prawo łowieckie ${ }^{20}$. Przykładowo wskazać można, iż A. Lipiński w oparciu o analizę przepisów szczególnych, wyróżnił cztery rodzaje ochrony zwierząt: humanitarną, użytkową, gatunkową oraz weterynaryjną ${ }^{21}$.

W Polsce idea praw zwierząt zyskuje na uznaniu również w świecie akademickim. Na Wydziale Prawa i Administracji Uniwersytetu Śląskiego są prowadzone zajęcia „Prawna ochrona zwierząt" 22 ; tematyka ta ujmowana jest również w ramach ogólnego wykładu z etyki ${ }^{23}$. Ponadto działa tam Koło Naukowe Praw Zwierząt oraz Sekcja Studenckiej Poradni Prawnej zajmująca się tą tematyką.

Przedstawiając historię regulacji prawnej ochrony zwierząt na ziemiach czeskich, autorzy wskazują, że od XV do połowy XIX wieku pewnych elementów można się dopatrywać w przepisach łowieckich, w regulacjach dotyczących prawa własności i odpowiedzialności za szkody wyrządzane przez zwierzęta, w szczegółowych regułach chowu bydła oraz w tzw. regulaminach targowisk. Pierwszym aktem prawnym było rozporządzenie z 1855 r. podpisane przez Alexandra von Bacha ${ }^{24}$, zawiera-

17 P. Kozłowska, M. Szwarczyk, Prawnokarna ochrona zwierząt, „Zamojskie Studia i Materiały" 2000, z. 1, s. 62-63.

18 Ustawa z 16 kwietnia 2004 r., o ochronie przyrody, tj. Dz. U. z 2013 r., poz. 627 ze zm.

19 Ustawa z dnia 18 kwietnia 1985 r. o rybactwie śródlądowym, Dz. U. 2013, poz. 628, 1158.

20 Ustawy z dnia 13 października 1995 r. Prawo łowieckie, tj. Dz. U. z 2013 r., poz. 1226 ze zm.

21 Zob. A. Lipiński, Prawne podstawy ochrony środowiska, Warszawa 2010, s. $185-186$.

${ }^{22}$ Zajęcia te prowadzą: Agnieszka Bielska-Brodziak oraz Tomasz Pietrzykowski.

23 Wykład z etyki prowadzi Tomasz Pietrzykowski.

24 Nařizeni Ministerstva vnitra ve shodě s Nejvyššim policejnim uřadem s platnosti pro všechny korunni země s vyjimkou vojenskych ujezdů. 
jące jeden zwięzły przepis o karalności publicznego dręczenia zwierząt. W ślad za tym rozporządzeniem trzy podstawowe części ziem czeskich wydały swoje przepisy: Śląsk w 1899 r., Morawy w 1901 r. i Królestwo Czeskie w 1902 r. Były one dość szczegółowe i z pewnymi uzupełnieniami obowiązywały w pierwszej międzywojennej Czechosłowacji aż do rozporządzenia rządu Protektoratu Czech i Moraw z 27 marca 1939 r. o ochronie zwierząt przed dręczeniem. Wprawdzie rozporządzenie to przygotował jeszcze rząd niepodległej Czechosłowacji, ale wprowadził je w życie dopiero rząd Protektoratu, zapewne dlatego nie zostało wykazane w dekrecie prezydenckim z 1944 r. o odnowieniu porządku prawnego i nie stało się częścią powojennego czechosłowackiego systemu prawnego. W okresie socjalizmu ustawodawca czechosłowacki interesował się tylko kolektywną wielką hodowlą zwierząt, i to wyłącznie pod kątem gospodarczym, a kwestia ochrony zwierząt przed dręczeniem została odsunięta na margines. Autorzy oceniają lata socjalizmu jako w zasadzie zastój w ochronie zwierząt, dopiero w 1987 r. zakaz dręczenia został wprowadzony do nowej wtedy ustawy weterynaryjnej ${ }^{25}$ $\mathrm{z}$ jednoczesnym uznaniem naruszenia tego zakazu za wykroczenie. Rozbudowane nowe regulacje prawne ochrony zwierząt pojawiły się po „aksamitnej rewolucji” roku 1989.

Pierwszym aktem regulującym kwestie ochrony zwierząt w Polsce było rozporządzenie Prezydenta Rzeczypospolitej z dnia 22 marca 1928 roku o ochronie zwierząt ${ }^{26}$ obowiązujące prawie siedemdziesiąt lat. Był to akt liczący zaledwie dwanaście artykułów. Zgodnie z art. 1: „Znęcanie się nad zwierzętami jest wzbronione. Za zwierzęta $\mathrm{w}$ rozumieniu niniejszego rozporządzenia uważa się wszelkie domowe i oswojone zwierzęta i ptactwo oraz zwierzęta i ptactwo dzikie, jako też ryby, płazy, owady i.t.p.”. W art. 2 sformułowana została definicja „znęcania się nad zwierzętami", z kolei przepis art. 3 wskazywał co nie będzie uważane za znęcanie się nad zwierzętami. Po 1971 roku w rozporządzeniu tym pozostało jedno przestępstwo oraz jed-

25 Zakon č. 87/1987 Sb., o veterinarni peči.

26 Rozporządzenie Prezydenta RP z dnia 22 marca 1928 r. o ochronie zwierząt, Dz. U. z 1932 r. Nr 42, poz. 417 z późn. zm. 
no wykroczenie ${ }^{27}$. Przestępstwo określone zostało w art. 5, w myśl którego jeżeli znęcania nad zwierzęciem „dopuszczono się w sposób, wskazujący na wyjątkowe okrucieństwo sprawcy, winny ulegnie karze więzienia do jednego roku". Z kolei wykroczenie stypizowane $\mathrm{w}$ art. 7 polegało na dokonywaniu doświadczeń naukowych $\mathrm{w}$ sposób naruszający postanowienia art. 3, lub przepisów wydanych na jego podstawie, zagrożone było karą grzywny 1000 zł. Na mocy art. 43 ustawy o ochronie zwierząt z dnia 21 sierpnia $1997 \mathrm{r}^{28}$, straciło moc rozporządzenie Prezydenta Rzeczypospolitej z dnia 22 marca 1928 r. $^{29}$

W Czechach początkowo sprawa ochrony zwierząt miała być uregulowana na poziomie federalnym, przygotowanie ustawy zostało powierzone Ministerstwu Gospodarki. Potem w związku z rozpadem federacji przygotowanie projektu przeszło na czeskie Ministerstwo Rolnictwa, którego projekt został aprobowany przez rząd republikański i stał się przedmiotem rozpatrzenia przez Czeską Radę Narodową dopiero wiosną 1992 r. Inspiracją były rozwiązania niemieckie, szwajcarskie i szwedzkie, przy czym projekt uwzględniał także konwencje Rady Europy, do których wtedy dopiero zamierzano przystąpić.

Podstawowa ustawa o ochronie zwierząt przed dręczeniem została uchwalona 15 kwietnia 1992 r. W wersji pierwotnej liczyła 30 paragrafów. Była ona trzynastokrotnie nowelizowana (ostatnia nowela z 2012 r. weszła w życie 1 stycznia 2013 r.), po czym jej rozmiary doszły do 103 rozbudowanych paragrafów. Zachowana systematyka regulacji opiera się na następujących filarach:

- wyznaczenie kręgu postępowań ze zwierzętami, które to postępowania są uznawane za dręczenie, proklamo-

27 Art. 4, 6 oraz 8 rozporządzenia z 1928 r., uchyliła ustawa z 20 maja 1971 r. Przepisy wprowadzające Kodeks wykroczeń (Dz. U. Nr 12, poz. 115; zm.: Dz. U. z 1982 r., Nr 35, poz. 228), natomiast przepisy odnoszące się do wykroczeń - przeniesione zostały do nowego Kodeksu wykroczeń, do rozdziału VIII („Wykroczenia przeciwko porządkowi i spokojowi publicznemu”).

28 Ustawa z dnia 21 sierpnia 1997 r. o ochronie zwierząt, Dz. U. 1997 Nr 111, poz. 724.

29 Zob. M. Mozgawa, Prawnokarna ochrona zwierząt, Lublin 2001, s. 14. 
wanie zakazu dręczenia wraz z zakazem propagowania dręczenia,

- zakaz uśmiercania zwierząt bez prawem przewidzianej przyczyny,

- podstawowe reguły chowu i ochrony zwierząt gospodarskich i zwierząt chowanych dla zainteresowań oraz podstawowe reguły ochrony zwierząt dziko żyjących,

- regulacja prowadzenia doświadczeń na zwierzętach i zasady ochrony zwierząt doświadczalnych,

- kompetencje organów ochrony zwierząt,

- delikty administracyjne i wykroczenia.

Obecnie obowiązująca polska ustawa o ochronie zwierząt została uchwalona 21 sierpnia 1997 roku zastąpiła rozporządzenie prezydenta RP z 22 marca 1928 roku o ochronie zwierząt. Zawiera ona 44 artykuły podzielone na dwanaście rozdziałów. Zakres tej ustawy - w odróżnieniu od uchylonego rozporządzenia - nie ogranicza się do humanitarnej ochrony zwierząt ${ }^{30}$. Uchwalona ustawa stanowi kompleksową i nowoczesną regulację odnoszącą się do ochrony zwierząt. Była ona kilkakrotnie nowelizowana.

Ustawa reguluje postępowanie ze zwierzętami kręgowymi (art. 2 ust. 1 u.o.z.), nie stosuje się jej jednak do procedur stanowiących doświadczenie w rozumieniu art. 2 pkt 6 ustawy z dnia 21 stycznia 2005 r. o doświadczeniach na zwierzętach ${ }^{31}$. Bowiem w wyniku nowelizacji ustawy o ochronie przyrody z 21 stycznia 2005 roku dotyczącej doświadczeń na zwierzętach, uchylony został rozdział 9 tej ustawy - o procedurach doświadczalnych z użyciem zwierząt oraz inne przepisy dotyczące doświadczeń, czyniąc z nich przedmiot odrębnej ustawy. Warto przypomnieć, iż w 2004 roku projekt odrębnej ustawy o doświadczeniach na zwierzętach pojawił się w parlamencie i został uchwalony. Spotkał się on jednak z krytyką, z powodu której Prezydent złożył

30 M. Nazar, Normatywna dereifikacja zwierząt - aspekty cywilnoprawne, [w:] Prawna ochrona zwierząt, pod red. M. Mozgawy, Lublin 2002, s. 129; W. Radecki, Ustawa o ochronie zwierząt. Komentarz, Warszawa 2012, s. 16;

31 Dz. U. Nr 33, poz. 289, z późn. zm. 
weto, którego Sejm nie odrzucił ${ }^{32}$. W wyniku tego projekt przerobiono i ostatecznie 21 stycznia 2005 roku została uchwalona odrębna ustawa o doświadczeniach na zwierzętach ${ }^{33}$.

Poszczególne rozdziały ustawy o ochronie zwierząt poświęcone są: zwierzętom domowym (rozdział 2), zwierzętom gospodarskim (rozdział 3), zwierzętom wykorzystywanym do celów rozrywkowych, widowiskowych, filmowych, sportowych i specjalnych (rozdział 4), rozdział 5 „Zwierzęta w ogrodach zoologicznych" został uchylony w 2004 roku ustawą o ochronie przyrody ${ }^{34}$. Kolejne rozdziały traktują o: zwierzętach wolno żyjących (dzikich) - rozdział 6, transporcie zwierząt - rozdział 7, zabiegach na zwierzętach - rozdział 8, jak już wyżej zostało powiedziane, rozdział 9 „Procedury doświadczalne na zwierzętach" został uchylony w 2005 roku ustawą o doświadczeniach na zwierzętach. W rozdziale 10 znajdują się unormowania dotyczące uboju, uśmiercania i ograniczania populacji zwierząt. Ustawą z dnia 6 czerwca 2002 roku o zmianie ustawy o ochronie zwierzą ${ }^{35}$ został dodany rozdział $10 \mathrm{a}$ „Nadzór nad przestrzeganiem przepisów o ochronie zwierząt". Rozdział 11 poświęcony został przepisom karnym, natomiast ostatni - rozdział 12 - wskazuje zmiany w przepisach obowiązujących, przepisy przejściowe i końcowe.

Autorzy, mając na uwadze to, że ochrona zwierząt jest już wykładana na uczelniach rolniczych, podjęli próbę przedstawienia podstawowych zasad prawnej ochrony zwierząt i przyczynienia się w ten sposób do stworzenia jakiejś części ogólnej tej podgałęzi prawa. Wyróżnili dziewięć następujących zasad:

1) zasada wysokiej wartości zwierząt (wyraża odrzucenie dawnego poglądu, że zwierzęta to tylko środki

32 S. Wikariak, Ochrona przyrody. Nie będzie ustawy o doświadczeniach na zwierzętach. Posłowie zmienili zdanie, „Rzeczpospolita” nr 154 z 3-4 lipca 2004 r.

33 Ustawa z dnia 21 stycznia 2005 r., o doświadczeniach na zwierzętach, Dz. U. nr 33, poz. 289.

34 Ustawa z dnia 16 kwietnia 2004 r., o ochronie przyrody, Dz. U. nr 92, poz. 880 .

35 Ustawa z dnia 6 czerwca 2002 roku o zmianie ustawy o ochronie zwierząt, Dz. U. Nr 135, poz. 1141. 
produkcji czy „rzeczy” przeznaczone tylko do służenia ludziom);

2) zasada opieki (człowiek ponosi odpowiedzialność za warunki życia zwierząt, które pod jego wpływem utraciły możliwość żyć poza niewolą);

3) zasada obniżania cierpienia (zakaz dręczenia jest kamieniem węgielnym wszystkich regulacji prawnych ochrony zwierząt);

4) zasada zakazu uśmiercania zwierząt bez prawnej przyczyny (w prawie czeskim wyraża się ona w wyczerpującym wyliczeniu przyczyn uzasadniających uśmiercenie zwierzęcia);

5) zasada respektowania naturalnych potrzeb zwierzęcia (kluczowym elementem welfare musi być stworzenie takich warunków chowu, aby zwierzęta zachowywały się - w takim zakresie, w jakim jest to możliwe - zgodnie ze swymi naturalnymi instynktami);

6) zasada odpowiedzialności chowającego (chowający nie zawsze musi być właścicielem);

7) zasada fachowości i kwalifikacji (określone działania wobec zwierząt mogą podejmować tylko osoby zdolne do tego fachowo lub wyszkolone);

8) zasada subsydiarności wykorzystania zwierzęcia (wykorzystanie żywego zwierzęcia dla określonego celu jest dopuszczalne tylko wtedy, gdy nie jest dostępne żadne inne rozwiązanie; chodzi przede wszystkim o doświadczenia);

9) zasada transparentności (wyraża dostęp do informacji; obejmuje m.in. dostęp do nietechnicznego streszczenia aprobowanego przez właściwy organ doświadczenia na zwierzętach).

W polskim piśmiennictwie problematyka zasad prawnej ochrony zwierząt nie stanowiła dotychczas przedmiotu studiów o bardziej rozbudowanym charakterze. Nie oznacza to oczywiście, że nie można pokusić się o ustalenie katalogu takich zasad. Oczywiste jest, że podejmując próbę usystematyzowania zasad prawnej ochrony zwierząt, trzeba ustalić kryterium przesądza3/2014 jące o tym, że określona reguła zostanie uznana za zasadę. Zało- 
żyć należy, że zasady prawnej ochrony zwierząt stanowią normy wyrażone w przepisach ustawy o ochronie zwierząt. Jako zasady uznajemy te normy, które mają znaczenie podstawowe dla ochrony zwierząt w Polsce, spełniając nadrzędną rolę wobec innych przepisów ustawy o ochronie zwierząt. Analiza przepisów ustawy nie budzi wątpliwości co do tego że naczelną zasadą prawnej ochrony zwierząt jest wyrażona w art. 5 ustawy zasada humanitarnego traktowania zwierząt. Wymaga ona, aby zwierzęta były traktowane w sposób uwzględniający ich potrzeby oraz by miały one zapewnioną opiekę i ochronę (art. 4 pkt 2). Zasada ta jest ściśle powiązana z art. 1 ustawy, zgodnie z którym zwierzę jest istotą żyjącą zdolną do odczuwania cierpienia. Wydaje się, ze nie ma żadnych przeszkód, aby poszerzyć katalog zasad prawnej ochrony zwierząt o inne normy mające charakter podstawowy (oczywiste jest, że „zasadniczość” zawsze będzie miała charakter ocenny), jednakże w piśmiennictwie najczęściej tego się nie czyni. Niezależnie od mogących znaleźć uzasadnienie w świetle przepisów ustawy rozmaitych katalogów zasad, można wyrazić myśl, iż będą one zawsze urzeczywistniały naczelną zasadę humanitarnego traktowania zwierząt. W świetle analizy przepisów aktualnie obowiązującej ustawy można zaproponować wyróżnienie zasady wysokiej wartości zwierząt (art. 1 wprost stanowi, że zwierzę nie jest rzeczą, nadto w art. 21 wskazano, że zwierzęta dzikie są dobrem ogólnonarodowym); zasadę zdolności odczuwania zwierząt (zdolności do przeżywania bólu); zasadę ochrony życia zwierząt (przypadki dopuszczające zabijanie zwierząt określone w art. 6 ustawy są wyjątkami od ogólnej zasady); zasadę zakazu stwarzania nieuzasadnionych zagrożeń i cierpień zwierzętom używanym do pracy (także w celach sportowych lub rozrywkowych); zasadę rozwoju i swobodnego bytu zwierząt wolno żyjących; zasadę zakazu stosowania okrutnych metod w chowie i hodowli zwierząt; zasadę zakazu znęcania nad zwierzętami (art. 6 ust. 1a, ust. 2), zasadę opieki nad zwierzętami domowymi i gospodarskimi (art. 9, art. 12 ustawy); zasadę opieki nad zwierzętami bezdomnymi, zasadę fachowości i kwalifikacji (np. rozdział 8 ustawy), zasadę nadzoru weterynaryjnego i inne. Podkreślić należy, iż liczba zaproponowanych zasad zawsze będzie uzależnio- 
na od tego, jak bardzo rozbudowany katalog zasad będzie starał się skonstruować w oparciu o obowiązujące przepisy ustawy autorytet wypowiadający się o zasadach. Niezależnie od tego, mając na uwadze zaproponowane powyżej zasady, stwierdzić należy, że w świetle przepisów polskich można wyprowadzić podobne zasady prawnej ochrony zwierząt, jak wymieniane w prawie czeskim, choć oczywiście różne może być w tej mierze nazewnictwo. Jest to związane $\mathrm{z}$ faktem, że zarówno prawo jednego, jak i drugiego kraju przyjęło ten sam kierunek odnośnie co do celów (postulatów), które winny realizować obowiązujące przepisy. Urzeczywistniają one idee ochrony praw zwierząt i ich humanitarnego traktowania; ustawy przewidują co prawda wyjątki od tej zasady (np. sytuacje w których jest dopuszczalne uśmiercenie zwierzęcia), ale są to tylko wyjątki od podobnych co do treści zasad o optymalizacyjnym charakterze.

Czeska definicja zwierzęcia ${ }^{36}$ obejmuje każdego żywego kręgowca, z wyjątkiem człowieka, ale z wyłączeniem płodu i embriona. $\mathrm{Z}$ tego wynika, że bezkręgowce nie są chronione przed dręczeniem. Autorzy dostrzegają, że w innych ustawach pojęcie zwierzęcia jest szersze, wobec czego uważają, że w przyszłości należy rozszerzyć ochronę przewidzianą w ustawie z 1992 r. co najmniej na te bezkręgowce, co do których badania naukowe wykażą, że mogą odczuwać cierpienie.

Polska ustawa o ochronie zwierząt nie zawiera definicji zwierzęcia ${ }^{37}$, jednak dotyczy ona wyłącznie zwierząt kręgowych. Zwrócić jednak należy uwagę na to, iż pierwotny projekt polskiej ustawy o ochronie zwierząt nie wprowadzał takiego ograniczenia. Jak wskazuje W. Radecki „Nie było podstaw ku temu, aby na gruncie polskiej ustawy o ochronie zwierząt ograniczyć pojęcie zwierzęcia do zwierzęcia kręgowego" ${ }^{38}$. Również przepisy rozporządzenia z 1928 r. o ochronie zwierząt uznawa-

36 W czeskich aktach prawnych pojawiają się trzy pojęcia: zviře jako najogólniejsze, živočich na oznaczenie zwierzęcia dziko żyjącego, zvěr oznaczające zwierzynę łowną.

37 Zob. I. Dobrowolska, G. Dobrowolski, Ochrona zwierząt. Nieprecyzyjne i niepetne przepisy, „Rzeczpospolita” z dnia 28.06.1998 r.

38 W. Radecki, Ustawa o ochronie..., s. 44. 
ły za zwierzęta wszelkie domowe i oswojone zwierzęta i ptactwo oraz zwierzęta i ptactwo dzikie, jak też ryby, płazy, owady itp. Regulacja ta nie ograniczała więc ochrony do zwierząt kręgowych, obejmując nią cały świat zwierzęcy. Biorąc pod uwagę powyższe, należy rozważyć czy w Polsce również nie należałoby pójść podobną - jak postulowana przez Hanę Müllerova i Vojtěcha Stejskala - drogą i wrócić do pojęcia „zwierzęcia” w rozumieniu przedwojennego rozporządzenia.

Kluczowe pojęcie dręczenia zostało zdefiniowane w §4 ustawy czeskiej w ten sposób, że najpierw pod lit. a) do v) ustawodawca wskazuje na 21 wariantów dręczenia, po czym pod lit. w) wskazuje na „inne zachowanie powodujące cierpienie”. Nie jest to więc wyliczenie zamknięte. Dlatego zdaniem autorów dla kwalifikacji działania jako dręczenia wystarczy spełnienie następujących znamion:

- chodzi o działanie (zgodnie z teoria prawa może nim być także zaniechanie) zabronione ustawą o ochronie zwierząt,

- istnieje związek przyczynowy między takim działaniem (zaniechaniem) a cierpieniem zwierzęcia.

Jednakże pojęcie dręczenia nie może być bezbrzeżne. Nowelą z 2012 r. zmieniono lit. w) w §4 przez dodanie, że chodzi o działanie ustawą zakazane, a nie o działanie jakiekolwiek, mimo że działania opisane pod lit. a) do v) to tylko przykłady. Istotna cechą prawa czeskiego jest to, że organ gminy orzekający w sprawach o wykroczenia i delikty dręczenia nie może sam ocenić działania jako dręczenia, lecz musi dysponować fachowym stanowiskiem organu administracji weterynaryjnej, że to rzeczywiście było dręczenie.

Dręczenie zwierzęcia jest co do zasady wykroczeniem lub innym deliktem administracyjnym ${ }^{39}$, może być przestępstwem

39 Czytelnikowi polskiemu należy się wyjaśnienie różnicy między odpowiedzialnością za wykroczenia (přestupky) a odpowiedzialnością za inne delikty administracyjne (jine spravni delikty). Co do zasady są to czyny takie same, ale jeżeli sprawcą jest osoba prawna lub osoba fizyczna będąca przedsiębiorcą, to odpowiada za delikt administracyjny według surowszych zasad (wina nie jest warunkiem odpowiedzialności), jeżeli zaś sprawcą jest osoba 
tylko wtedy, gdy działanie wyczerpuje kodeksowe znamiona przestępstwa, o czym w dalszym ciągu rozważań.

Polska ustawa o ochronie zwierząt $\mathrm{w}$ art. 6 ust. 1a zabrania znęcania się nad zwierzętami. Zgodnie z ust. 2 tego artykułu: „przez znęcanie się nad zwierzętami należy rozumieć zadawanie albo świadome dopuszczanie do zadawania bólu lub cierpień". Ustawowa definicja rozróżnia pojęcie cierpienia oraz bólu, w związku z tym rodzi się pytanie co one oznaczają. W. Radecki zaproponował przyjęcie cywilistycznego ujęcia oraz podziału na ból fizyczny i cierpienie (psychiczne) ${ }^{40}$. Jednakże na gruncie prawa karnego oba pojęcia oznaczają to samo, bowiem zarówno ból, jak i cierpienie mogą mieć charakter fizyczny i psychiczny ${ }^{41}$. Znęcanie się nad zwierzęciem - inaczej niż w Czechach - zawsze jest przestępstwem, które może być popełnione wyłącznie $\mathrm{w}$ formie umyślnej. Zgodnie $\mathrm{z}$ art. 35 ust. 1a u.o.z. kto znęca się nad zwierzęciem podlega karze takiej samej jak ten kto zabija, uśmierca zwierzę albo dokonuje uboju zwierzęcia z naruszeniem przepisów art. 6 ust. 1, art. 33 lub art. 34 ust. 1-4 u.o.z. Czyn ten zagrożony jest grzywną, karą ograniczenia wolności albo pozbawienia wolności do lat 2 . Natomiast jeżeli sprawca działa ze szczególnym okrucieństwem, to zgodnie z art. 35 ust. 2 u.o.z., podlega karze pozbawienia wolności do lat 3. W doktrynie polskiej powstają jednak spory, czy czyn znęcania się może zostać popełniony tylko z zamiarem bezpośrednim czy także z zamiarem ewentualnym. Analiza dorobku doktryny i orzecznictwa polskiego nie daje jednoznacznego rozstrzygnięcia ${ }^{42}$.

fizyczna niebędąca przedsiębiorcą, to odpowiada za wykroczenie (wina jest wtedy warunkiem odpowiedzialności).

40 W. Radecki, Ustawy: o ochronie zwierząt, o doświadczeniach na zwierzętach - z komentarzem, Warszawa 2007, s. 60.

41 Zob. M. Gabriel-Węglowski, Przestępstwa przeciwko humanitarnej ochronie zwierząt, Toruń 2008, s. 98.

42 Za przyjęciem wyłącznie zamiaru bezpośredniego opowiadają się m.in.: I. Andrejew, Kodeks karny - krótki komentarz, Warszawa 1986, s. 165; K. Buchała, A. Zoll, Kodeks karny. Część szczególna. Komentarz, t. II, Kraków 1998, s. 615-616. Za przypisaniem sprawcy czynu znęcania się zamiaru ewentualnego: L. Gardocki, Prawo karne, Warszawa 1998, s. 252 oraz M. Siewierski [w:] J. Bafia, K. Miodulski, M. Siewierski, Kodeks karny. Komentarz, Warszawa 
W kwestii uśmiercania zwierząt §5 ustawy wyznacza taksatywnie przyczyny na to zezwalające obejmując wykorzystanie produktów zwierzęcych (mięsa, wełny, skór itd.), konieczność uśmiercenia ze względu na nieodwracalną słabość, chorobę, zranienie itp., bezpośrednie zagrożenie człowieka przez zwierzę, wykonywanie prawa polowania i rybołówstwa, wykonywanie zalecenia służby weterynaryjnej lub higienicznej wydanego ze względu na zapobieganie chorobom zakaźnym, zakończenie doświadczenia, po którym zwierzę należy uśmiercić, deratyzację i kilka innych powodów. Uśmiercenie zwierzęcia bez prawem dopuszczonego powodu jest deliktem administracyjnym lub wykroczeniem.

Zgodnie z polską ustawą uśmiercanie zwierząt może odbywać się wyłącznie w sposób humanitarny polegający na zadawaniu przy tym minimum cierpienia fizycznego i psychicznego (art. 33 ust. 1a u.o.z.). Co do zasady uśmiercenie może nastąpić za zgodą właściciela. Jednak art. 33 ust. 2 u.o.z. stanowi, że zwierzę może być uśmiercone bez zgody właściciela na podstawie orzeczenia lekarza weterynarii, jeżeli stanowić może przyczynę działań niezbędnych do usunięcia poważnego zagrożenia sanitarnego ludzi lub zwierząt. Należy jednak zwrócić uwagę na to, iż uśmiercanie w Polsce jest przestępstwem, o czym mowa była już wyżej.

Z uśmiercaniem wiążę się problem uboju rytualnego. Przepis dopuszczający taki ubój został wprowadzony do czeskiej ustawy o ochronie zwierząt ze względu na konstytucyjnie gwarantowane prawo swobodnego przejawiania wyznań religijnych i wiary ${ }^{43}$. W warunkach czeskich chodzi o ubój bez uprzedniego pozbawienia świadomości praktykowany przez żydów i muzułmanów. Ubój zwierząt bez uprzedniego pozbawienia świadomości jest zakazany przez prawo europejskie (art. 4 rozporzą-

1987, s. 179. Również W. Radecki dopuszcz przypisanie zamiaru ewentualnego, ale wyłącznie w odniesieniu do typu kwalifikowanego przez szczególne okrucieństwo, zob. W. Radecki, Ustawy..., s. 167.

43 Prawo to gwarantuje art. 16 Karty Podstawowych Praw i Wolności ( $L i$ stina zakladnich prav a svobod), przyjętej jeszcze w czasach federacji 9 stycznia 1991 r. Po rozpadzie Czechosłowacji Karta stała się częścią składową systemu konstytucyjnego Republiki Czeskiej. 
dzenia unijnego 1099/2009), a tym samym czeskie. Regulacja uboju rytualnego jest wyjątkiem od tej zasady. Przewiduje ją §5f ustawy o ochronie zwierząt. Pozwolenie wydaje związkowi religijnemu Ministerstwo Rolnictwa na czas nie dłuższy niż rok. Regionalna administracja weterynaryjna określa warunki weterynaryjne takiego uboju w konkretnych rzeźniach. Takiego uboju może dokonywać tylko osoba mająca odpowiednie kwalifikacje fachowe, tylko w rzeźni i zawsze pod bezpośrednią kontrolą weterynaryjną. Jak podają autorzy, w Republice Czeskiej w 2011 r. ministerstwo udzieliło 11 takich pozwoleń, obejmujących zarówno kosher, jak i halal.

Obecnie obowiązujący stan prawny w Polsce w zakresie uboju rytualnego nie tworzy przemyślanej ani konsekwentnej struktury. „Jego centrum stanowi konflikt pomiędzy ochroną dobrostanu zwierząt a swobodą kultu religijnego"44. Dnia 1 stycznia 2013 roku weszło w życie rozporządzenie Rady i Parlamentu Europejskiego 1999/2009 z 24 września 2009 roku w sprawie ochrony zwierząt podczas ich uśmiercania, które wprowadziło nakaz ogłuszania z wyjątkiem uboju na potrzeby kultu religijnego (czyli rozwiązanie identyczne jak w polskiej ustawie o ochronie zwierząt obowiązującej w latach 1997-2002). Jak wskazuje Tomasz Tadeusz Koncewicz, interpretacja całościowa tego rozporządzenia prowadzi do wniosku o odstąpieniu od głuszenia wyjątkowo, na potrzeby uboju rytualnego, po spełnieniu łącznie dwóch warunków: „ubój musi być przeprowadzany według szczególnych metod wymaganych przez obrzędy religijne i dla celów tych obrzędów. Oba te warunki służą zapewnieniu racjonalnego kompromisu godzącego z jednej strony wolność wyznania i prawo do uzewnętrzniania religii z ochroną praw zwierząt

44 E. Łętowska, M. Namysłowska, M. Grochowski, A. Wiewiórowska-Domagalska (EMMA), Prawo UE o uboju zwierząt i jego polska implementacja: kolizje interesów i ich rozwiązanie (cz. II), „Europejski Przegląd Sądowy”, grudzień 2013, s. 4. O handlowym wymiarze tego problemu pisali: W. Brzozowski, Dopuszczalność uboju rytualnego w Polsce, „Państwo i Prawo” 2013, Nr 5, s. 47; K. Lipińska, Czy w Polsce jest dozwolony rytualny ubój zwierzq̨t?, „Przegląd Prawa Ochrony Środowiska" 2011, Nr 1, s. 13. 
z drugiej”45. Polski rząd po serii „awantur” 1 stycznia 2013 roku zgłosił Komisji Europejskiej deklarację, iż utrzymuje wyższy poziom ochrony zwierząt i zawsze wymaga głuszenia. W wyniku tego w Polsce obecnie obowiązuje ustawa o ochronie zwierząt z 1997 roku, przewidująca bezwzględny obowiązek głuszenia zwierząt, nie regulując przy tym kwestii uboju rytualnego.

Po dwuletniej vacatio legis, 1 stycznia 2014 r. wszedł w życie nowy czeski kodeks cywilny ${ }^{46}$. W $\S 494$ tego kodeksu ustawodawca czeski określił status zwierząt w sposób następujący: „Żywe zwierzę ma szczególne znaczenie i wartość jako obdarzone zmysłami żywe stworzenie. Żywe zwierzę nie jest rzeczą, a przepisy o rzeczach stosuje się do niego odpowiednio tylko w zakresie, w jakim nie jest to sprzeczne z jego charakterem". Komentując to rozwiązanie, autorzy wskazują, że przynosi ono jasne etyczne przesłanie formułujące pożądane podejście społeczeństwa do zwierząt. Jest ważną wskazówką interpretacyjną istniejących przepisów, ale także inspiracją dla tworzenia przepisów w przyszłości. Akcentują, że (inaczej niż w ustawie o ochronie zwierząt) pojęcie zwierzęcia nie ogranicza się do kręgowców, lecz obejmuje także bezkręgowce, jeżeli zdatne są do odczuwania cierpienia lub stresu. Za zaskakujące uznają to, że ustawodawca określił, czym żywe zwierzę (martwe zwierzę jest na pewno rzeczą) nie jest, ale pozostawił otwartym pytanie, czym jest. Zdaniem autorów ustawodawca nie przesunął żywych zwierząt do kategorii podmiotów prawa, są nadal przedmiotami stosunków prawnych, ale jakąś szczególną kategorią sui generis. Zastanawiając się nad tym, co to znaczy, że przepisy dotyczące rzeczy stosują się odpowiednio, ale tylko w zakresie niesprzecznym ze statusem zwierzęcia, posługują się kapitalnym przykładem, że nie wolno oddać psa lgnącego do swego

45 T. T. Koncewicz, Państwo prawa ubite rytualnie, „Rzeczpospolita” z 24 czerwca 2014 r., c8.

46 Zakon č. 89/2012 Sb., občansky zakonik. Liczy 3081 paragrafów w podziale na: część ogólną (§ 1-654), prawo rodzinne (§ 655-975), absolutne prawa majątkowe (§ 976-1720), relatywne prawa majątkowe (§ 1721-3014), przepisy wspólne, przechodnie i końcowe (§ 3015-3081). 
pana w zastaw obcemu człowiekowi, u którego pies byłby narażony na stres.

Ustawodawca polski przesądził $\mathrm{w}$ art. 1 ust. 1 u.o.z., że zwierzę jest istotą żyjącą, zdolną do odczuwania i cierpienia i nie jest traktowane jako rzecz. Nie tylko więc nie jest ono rzeczą (w znaczeniu techniczno-prawnym), ale również nie jest przedmiotem materialnym, będąc istotą żyjącą, zdolną do odczuwania cierpienia. Brzmienie przepisu art. 1 ust. 1 u.o.z. wskazuje, że jego celem jest „odprzedmiotowienie” zwierząt ${ }^{47}$.

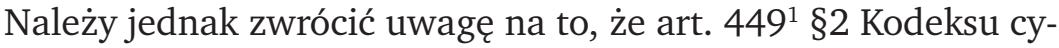
wilnego ${ }^{48}$, który został wprowadzony po wejściu w życie ustawy o ochronie zwierząt, nakazuje za produkt (czyli rzecz ruchomą) uważać także zwierzęta.

Przechodząc do problematyki ochrony zwierząt w prawie karnym, autorzy zatrzymują się nad przepisami §302 i 303 czeskiego kodeksu karnego ${ }^{49}$, zamieszczonymi w rozdziale VIII części szczególnej „Przestępstwa przeciwko środowisku”. Te dwa przepisy przytoczymy w pełnym brzmieniu.

Pierwszy z nich, §302 pod nagłówkiem „Dręczenie zwierząt"50 stanowi:

1) Kto dręczy zwierzę:

a) szczególnie brutalnym lub męczącym sposobem,

b) brutalnym lub męczącym sposobem publicznie lub w miejscu publicznie dostępnym,

47 M. Nazar, Normatywna dereifikacja..., s. 132. Szerzej na ten temat także: E. Łętowska, Dwa cywilnoprawne aspekty prawa zwierząt: dereifikacja i personifikacja, [w:] Studia z prawa prywatnego. Księga pamiątkowa ku czci Profesor Biruty Lewaszkiewicz-Petrykowskiej, A. Szpunar (red.) W. J. Katner, T. Pajor, M. Pyziak-Szafnicka, U. Promińska, E. Wojnicka, Łódź 1997, s. 71-92.

48 Ustawa z dnia 23 kwietnia 1964 r. - Kodeks cywilny, tj. Dz. U. 2014, poz. 121.

49 Zakon č. 40/2009 Sb., trestni zakonik. Czytelnikowi polskiemu należy się wyjaśnienie, że w Czechach (inaczej niż w Polsce) miejscem typizacji przestępstw jest wyłącznie kodeks karny, a polska kategoria „przestępstw pozakodeksowych” po prostu nie istnieje, znamiona czynów uznawanych za przestępstwa muszą znaleźć się w kodeksie karnym.

50 W oryginale: Tyrani zviřat. 
zostanie ukarany pozbawieniem wolności do lat 2, zakazem prowadzenia działalności albo przepadkiem rzeczy lub innej wartości majątkowej.

2) Pozbawieniem wolności od 6 miesięcy do lat 3 zostanie sprawca ukarany:

a) jeżeli był za czyn określony w ust. $1 \mathrm{w}$ ostatnich trzech latach osądzony lub ukarany, albo

b) jeżeli takim czynem spowoduje u dręczonego zwierzęcia trwałe następstwa dla zdrowia albo śmierć.

3) Pozbawieniem wolności od roku do lat 5 zostanie sprawca ukarany, jeżeli popełni czyn określony w ust. 1 na większej liczbie zwierząt.

Drugi, §303 pod nagłówkiem „Zaniedbanie pieczy o zwierzę z niedbalstwa" ${ }^{51}$ stanowi:

1) Kto z rażącego niedbalstwa zaniedba niezbędnej pieczy o zwierzę, którym włada albo o które $\mathrm{z}$ innego powodu ma obowiązek się troszczyć, i spowoduje mu tym trwałe następstwa dla zdrowia lub śmierć, zostanie ukarany pozbawieniem wolności do 6 miesięcy, zakazem prowadzenia działalności albo przepadkiem rzeczy lub innej wartości majątkowej.

2) Pozbawieniem wolności do lat 2 zostanie sprawca ukarany, jeżeli spowoduje czynem określonym w ust. 1 śmierć lub trwałe następstwa dla zdrowia większej liczby zwierząt.

Autorzy prowadzą szczegółową analizę znamion tych dwóch przestępstw, z uznaniem podkreślając wprowadzenie odpowiedzialności także za przestępstwa nieumyślne w §303.

W polskim Kodeksie Karnym ${ }^{52}$ brak rozwiązań odpowiadających unormowaniom czeskim. Co prawda rozdział XXII penalizuje „Przestępstwa przeciwko środowisku”, jednakże w świetle treści zawartych $\mathrm{w}$ nim przepisów trudno mówić o efektywnej ochronie zwierząt. W art. $181 \S 1$, który stanowi, iż „Kto powoduje zniszczenie w świecie roślinnym lub zwie-

51 W oryginale: Zanedbani peče o zviře z nedbalosti.

52 Ustawa z dnia 6 czerwca 1997 r., Kodeks karny, Dz. U. z 1997 r. Nr 88, poz. 553 ze zm. 
rzęcym w znacznych rozmiarach, podlega karze pozbawienia wolności od 3 miesięcy do lat 5" ustawodawca chroni nie konkretne zwierzęta, lecz „świat zwierzęcy” jako całość. Samo pojęcie „świat zwierzęcy" wydaje się bardzo wieloznaczne, nadto penalizowane jest wyłącznie wyrządzenie szkody w znacznych rozmiarach. Z kolei w §2 art. 181, który stanowi, iż „Kto, wbrew przepisom obowiązującym na terenie objętym ochroną, niszczy albo uszkadza rośliny lub zwierzęta powodując istotną szkodę, podlega grzywnie, karze ograniczenia wolności albo pozbawienia wolności do lat 2” prawodawca mówi o „niszczeniu lub uszkodzeniu" zwierząt (cokolwiek to oznacza), a nie o ich zabiciu (wydaje się, że same słowa „niszczy” bądź „uszkadza" w języku są stosowane wobec roślin, trudno natomiast w ogóle odnieść je do zwierząt), nadto przepis ten odnosi się wyłącznie do terenu objętego ochroną (§3 rozszerza ochronę co do zwierząt pozostających pod ochroną gatunkową), a spowodowana szkoda musi być istotna. Kodeks karny, co prawda wprowadza odpowiedzialność za nieumyślne popełnienie tych czynów (art. 181 §4 i 5), jednakże nie budzi wątpliwości to, iż przedmiotem ochrony jest tu środowisko jako całość, którego jeden z elementów stanowią zwierzęta, nie zaś konkretne zwierzę (wydaje się, że do wyjątków będzie należało stosowanie art. 181 §2 i 3 w przypadku „zniszczenia” zwierzęcia/zwierząt szczególnie rzadkich, co w efekcie spowoduje istotną szkodę dla środowiska). Przepisy $\mathrm{w}$ jakimś stopniu odpowiadające rozwiązaniom czeskim wprowadzono w rozdziale 11 ustawy o ochronie zwierząt, w szczególności w art. 35 ustawy, który między innymi penalizuje zabicie, uśmiercenia oraz znęcanie się nad zwierzętami. Porównanie rozwiązań obydwu krajów karze jednakże uznać ochronę przyznaną zwierzętom przez przepisy polskie za daleko niewystarczającą, w szczególności zaniechaniem prawodawcy polskiego jest brak wprowadzenia odpowiedzialności za czyny popełnione nieumyślnie. Wydaje się, że należy postulować wprowadzenie takiej odpowiedzialności - czeski §303 jest tu niewątpliwie dobrym wzorem.

W końcowej części rozważań o odpowiedzialności karnej autorzy odnoszą się do czeskiej ustawy o odpowiedzialno- 
ści karnej osób prawnych ${ }^{53}$. Ustawa ta w wykazie przestępstw, które mogą popełnić osoby prawne, ujmuje liczne przestępstwa przeciwko środowisku, ale przestępstw z §302 i 303 wśród nich nie ma. To stanowisko ustawodawcy czeskiego spotkało się z negatywną oceną autorów, którzy wskazali, że łatwo wyobrazić sobie można popełnienie takich przestępstw przez będące osobami prawnymi spółdzielnie rolnicze, fermy hodowlane, ośrodki rehabilitacji zwierząt, ogrody zoologiczne czy schroniska dla zwierząt. Pociągnięcie ich do odpowiedzialności karnej byłoby pożądane, ale w obowiązującym czeskim stanie prawnym nie jest możliwe.

Polska ustawa o ochronie zwierząt również nie przewiduje odpowiedzialności podmiotów zbiorowych za przestępstwa $\mathrm{z}$ art. 35 ustawy o ochronie zwierząt. Jednak być może warto wziąć pod rozwagę propozycję czeskich autorów, postulujących włączenie przepisów o przestępnym dręczeniu do uzasadniających odpowiedzialność osób prawnych.

W końcowych partiach opracowania autorzy zatrzymują się nad ochroną zwierząt $\mathrm{w}$ przepisach o ochronie przyrody, łowieckich i rybackich, wskazując, że także wśród nich można znaleźć regulacje służące ochronie zwierząt $\mathrm{w}$ tym podstawowym rozumieniu, tj. ochronie przed dręczeniem. Spotyka się je w mocno rozbudowanych przepisach o zabronionych sposobach polowania i rybołówstwa, aczkolwiek przy zakazie dręczenia chodzi o zwierzę jako indywiduum, podczas gdy w przepisach o ochronie przyrody, łowieckich i rybackich chodzi raczej o populacje zwierząt. Interesujące jest, że autorzy nie kwestionują zasadności tych przepisów czeskiej ustawy łowieckiej, które uprawniają straż łowiecką i gospodarza łowieckiego do uśmiercania psów i kotów włóczących się w obwodach łowieckich bez dozoru człowieka w odległości większej niż 200 m od najbliższej zamieszkałej nieruchomości, do uśmiercania zdziczałych zwierząt gospodarskich swobodnie poruszających się w odległości większej niż $200 \mathrm{~m}$ od granic ferm hodowlanych, do uśmiercania niepożądanych w czeskiej przyrodzie gatunków:

53 Zakon č. 418/2011 Sb., o trestni odpovědnosti pravnickych osob a řizeni proti nim. 
jenota, szopa pracza, norki amerykańskiej i nutrii rzecznej. Ale także $\mathrm{w}$ takich przypadkach należy, ich zdaniem, kierować się przepisami o zakazanych sposobach uśmiercania zwierząt. Autorzy dostrzegają, że w tych przypadkach nie chodzi o wykonywanie uprawnień do polowania, a prawnego usprawiedliwienia uśmiercania zwierząt dopatrują się $\mathrm{w}$ tych przepisach $\S 5$ czeskiej ustawy o ochronie zwierząt, które dopuszczają uśmiercanie w celu ochrony dziko żyjących populacji zwierząt.

Także w Polsce, w ostatnich latach, w przestrzeni publicznej oraz w mediach zaobserwować można było burzliwą dyskusję odnośnie do uprawnienia myśliwych do zwalczania (użycia broni palnej) zdziczałych psów i kotów stanowiących zagrożenie dla zwierząt dziko żyjących. W dyskursie prowadzonym $\mathrm{w}$ tej materii, $\mathrm{z}$ jednej strony podnoszony był przez myśliwych argument o konieczności ochrony zwierząt dziko żyjących, w szczególności saren i zajęcy przed zdziczałymi zwierzętami ${ }^{54}$, z drugiej strony organizacje obrony praw zwierząt podnosiły zarówno nadużywanie przez myśliwych tego uprawnienia, jak również niehumanitarny charakter samej idei strzelania do psów i kotów przez myśliwych ${ }^{55}$. Spór w tej materii przybrał na sile zwłaszcza po zgłoszeniu w parlamencie propozycji nowelizacji przepisów pozbawiających dzierżawców i zarządców obwodów łowieckich uprawnienia do zwalczania zdziczałych psów i kotów, która m.in. została negatywnie oceniona w toku konsultacji resortowych. Efektem prowadzonego dyskursu, w którym niewątpliwie ścierały się rozmaite ideologie oraz interesy, było znowelizowanie na mocy ustawy z dnia 16 września 2011 r.

54 Powszechnie wskazuje się na niemożność ustalenia kryteriów, które świadczą o „zdziczeniu” zwierzęcia. Nie były rzadkością przypadki, że już po zastrzeleniu psa przez myśliwego, sądy powoływały biegłych z zakresu kynologii dla dokonania ustaleń w tej materii.

55 W trakcie trwania prac legislacyjnych Polski Związek Łowiecki wydał oświadczenie, że na terenach łowieckich w Polsce kłusuje 950 tys. psów i 655 tys. kotów, które w 2009/2010 r. zagryzły 10 tys. saren i prawie 15 tys. zajęcy. Jednocześnie dane z 1996 r. mówią o zastrzeleniu 80 tys. psów; dane cyt. za E. Siedlecka, Myśliwi wciąż moga strzelać do psów, „Gazeta Wyborcza” z dnia 28 kwietnia 2011 r. Nadto wskazuje się, że w latach 2003-2010 zdziczałe zwierzęta domowe zabiły 222 tys. sztuk zwierzyny łownej; dane cyt za

3/2014 A. Dryszel, Licencja na zabijanie, „Przegląd” 2001, Nr 12. 
o zmianie ustawy o ochronie zwierząt oraz ustawy o utrzymaniu czystości i porządku w gminach (Dz. U. z 2011 r. Nr 230, poz.1373) art. 33a w ten sposób, iż pozbawiono dzierżawców i zarządców obwodów łowieckich prawa do zwalczania zdziczałych psów i kotów przebywających bez opieki i dozoru człowieka na terenie obwodów łowieckich w odległości większej niż $200 \mathrm{~m}$ od zabudowań mieszkalnych, stanowiących zagrożenie dla zwierząt dziko żyjących $\mathrm{w}$ to miejsce wprowadzając przepisy uprawniające do pouczenia właściciela psa o obowiązku sprawowania kontroli nad zwierzęciem oraz odłowienia psa i dostarczenie go właścicielowi bądź gdy nie jest możliwe jego dostarczenie do schroniska dla zwierząt, na koszt właściciela. Obecnie obowiązujące przepisy, realizujące postulaty zgłoszone przez organizacje obrońców praw zwierząt, są negatywnie ocenione przez środowiska łowieckie, które wskazując ich nieefektywność, podnoszą okoliczności w postaci zwiększenia szkód powodowanych przez zdziczałe zwierzęta domowe.

W końcowych partiach działa autorzy dają wyraz przekonaniu, że pozycja prawna zwierząt będzie się dalej zwiększała. Ale, ich zdaniem, obecnie znajdujemy się na jakimś skrzyżowaniu i żadna droga nie jest z góry wyłączona. Droga kontynuacji stosowania dzisiejszych instrumentów prawnych prowadzi do dalszego zaostrzania ochrony i welfare zwierząt opartych na powinnościach człowieka wobec nich. Droga dyskontynuacji mogłaby polegać na umocowaniu prawnym jakiegoś stopnia i jakiejś postaci podmiotowości prawnej i praw zwierząt. Nie da się dziś odpowiedzieć na pytanie, czy społeczeństwo wybierze drogę wzmacniania ochrony zwierząt zbudowanej na położeniu akcentu na odpowiedzialność człowieka, czy też drogę wprowadzenia praw zwierząt. Autorzy apelują o to, aby wskutek nadużywanej retoryki praw zwierząt nie osłabła świadomość ludzkiej odpowiedzialności. Antropocentryczne widzenie świata, nadal prawnie uznawane, aczkolwiek dziś często i w dużym stopniu zasadnie krytykowane, jawi się autorom jako nadal umocowane, zwłaszcza jeżeli będziemy je interpretować tak, że człowiek niesie odpowiedzialność za ochronę całej przyrody, wszakże a priori nie dla siebie, ale (także) dla niej samej. Ustawienie poszczególnych części przyrody, zwłaszcza żywej przyro- 
dy, nie jako podmiotów prawa, ale jako ważnych przedmiotów ochrony, jawi się autorom jako właściwy kierunek przyszłych rozważań także w przypadku problemu zwierząt.

Także w polskim piśmiennictwie problematyka prawnego statusu zwierząt jest obecnie coraz ważniejszym tematem w dyskursie etyczno-prawnym (prace T. Pietrzykowskiego i J. Białocerkiewicza). W nauce prawa można zaobserwować dwa nurty, pierwszy z nich, widoczny między innymi w pracach dogmatycznych z zakresu cywilistyki za podmioty prawa uznaje wyłącznie ludzi - człowiek jako podmiot prawa powinien zapewnić ochronę interesom zwierząt, podobnie jak chroni inne dobra wspólne (np. zabytki) ${ }^{56}$. W tym nurcie zwierzętom należy się ochrona, ale nie są one traktowane jako podmioty prawa posiadające zdolność odczuwania. Zwolennicy idei praw zwierząt zaprezentowaną powyżej ideę prawnego kształtowania statusu zwierząt uważają za wysoce niewystarczającą, z tego powodu, iż jak pisze T. Pietrzykowski „w praktyce zapewniają one znacznie mniej, niż »obiecują«, ale przede wszystkim dlatego, że nawet to, co obiecują opiera się na założeniu jedynie łagodzenia »niepotrzebnych« cierpień zwierząt, a nie respektowania przysługujących im uprawnień" ${ }^{57}$. Z uwagi na powyższe opowiadają się oni za wyłączeniem zwierząt z kategorii rzeczy stanowiących własność człowieka (nawet jeżeli winien on zapewnić im ochronę) i przyznanie im statusu podmiotów prawa. Kompromisowe propozycje postulują przyjęcie podmiotowości funkcjonalnej zwierząt tj. przyznanie zwierzętom jako istotom żyjącym pewnych praw w sensie materialnym (nie cywilnoprawnym) i jednocześnie nałożenie na ludzi obowiązku ich przestrzegania

Polska ustawa w art. 1 wyłączyła zwierzę z kategorii rzeczy, uznając zwierzęta za istoty żyjące, zdolne do odczuwania cierpienia, którym człowiek jest winien poszanowanie ochronę

56 Uzasadnieniem tego stanowiska jest m.in. argument, że zwierzęta nie stanowią podmiotu obowiązków prawnych, dlatego też nie można mówić o ich uprawnieniach, które winny być skorelowane z obowiązkami.

57 T. Pietrzykowski, Etyczne problemy prawa. zarys wykładu, Katowice 2005, s.374. 
i opiekę. Nie przyznała ona jednakże jednocześnie zwierzętom podmiotowości prawnej, m.in. stanowiąc, że w sprawach nieuregulowanych $\mathrm{w}$ ustawie stosuje się odpowiednio przepisy dotyczące rzeczy. Wydaje się, iż obecnie obowiązujące $w$ tej materii przepisy $\mathrm{w}$ Polsce są bardzo dobrą ilustracją owego skrzyżowania, o którym wspominają Hana Müllerova i Vojtěch Stejskal. Wybór dalszej drogi niewątpliwie będzie stanowił dla ustawodawcy wyzwanie w świetle rozmaitych ścierających się poglądów, ale i interesów związanych z wykorzystaniem zwierząt przez człowieka. W obecnym stanie dyskursu o prawach zwierząt, podzielić trzeba pogląd Hany Müllerovej i Vojtěcha Stejskala, że trudno jednoznacznie odpowiedzieć na pytanie o dalszą drogę co do prawnych regulacji dotyczących statusu zwierząt. Zgodzić się należy jednakże z autorami recenzowanej monografii, iż niezależnie od kierunku dalszych zmian, pozycja prawna zwierząt będzie coraz silniejsza. Wydaje się, że z uwagi na dotychczasowy kierunek ewolucji przepisów prawa odnoszących się do zwierząt, z pewną ostrożnością prognozować należy w krótszej bądź dłuższej perspektywie przyznanie zwierzętom, bądź pewnym ich grupom, jakiejś formy podmiotowości prawnej (znajduje to m.in. uzasadnienie w „zasadzie krzywdy"); oczywiste jest, iż owa konstrukcja podmiotowości winna gwarantować także ochronę określonych interesów ludzi, w tym także tych o charakterze ekonomicznym.

Kończąc te z natury rzeczy krótkie i odnoszące się tylko do niektórych problemów uwagi po części recenzenckie w znaczeniu opisowym, po części komparatystyczne, chcielibyśmy zaakcentować, że:

- po pierwsze, dzieło Hany Müllerovej i Vojtěcha Stejskala jest dojrzałym opracowaniem naukowym zawierającym nie tylko przebogatą warstwę informacyjną przedstawioną na wysokim poziomie, dochodzącym do finezyjnej analizy obowiązujących czeskich przepisów prawnych, lecz także interesujące, dobrze umotywowane poglądy teoretyczne,

- po drugie, znaczenie dzieła daleko wykracza poza sam czeski system prawny, stanowi ono ważne wzbogacenie literatury światowej poświęconej ochronie zwierząt, 
- po trzecie, z kart książki przebija głębokie zaangażowanie emocjonalne autorów po stronie zwierząt, niekiedy wręcz pasja, ale to zaangażowanie nie zmniejsza, lecz przeciwnie - zwiększa wartość dzieła duetu autorskiego, co z ukontentowaniem podkreślić pragnie duet recenzencki.

\section{BIBLIOGRAFIA}

Andrejew I., Kodeks karny - krótki komentarz, Warszawa 1986.

Bafia J., Miodulski K., Siewierski M., Kodeks karny. Komentarz, Warszawa 1987.

Brzozowski W., Dopuszczalność uboju rytualnego w Polsce, „Państwo i Prawo" 2013, Nr 5.

Buchała K., Zoll A., Kodeks karny. Część szczególna. Komentarz, t. II, Kraków 1998.

Gabriel-Węglowski M., Przestępstwa przeciwko humanitarnej ochronie zwierząt, Toruń 2008.

Gardocki L., Prawo karne, Warszawa 1998.

Kozłowska P., Szwarczyk M., Prawnokarna ochrona zwierząt, „Zamojskie Studia i Materiały" 2000, z. 1.

Lipińska K., Czy w Polsce jest dozwolony rytualny ubój zwierząt?, „Przegląd Prawa Ochrony Środowiska" 2011, Nr 1.

Lipiński A., Prawne podstawy ochrony środowiska, Warszawa 2010.

Łętowska E., Dwa cywilnoprawne aspekty prawa zwierzat: dereifikacja i personifikacja, [w:] Studia z prawa prywatnego. Księga pamiatkowa ku czci Profesor Biruty Lewaszkiewicz-Petrykowskiej, A. Szpunar (red.) W. J. Katner, T. Pajor, M. Pyziak-Szafnicka, U. Promińska, E. Wojnicka, Łódź 1997.

Łętowska E., Namysłowska M., Grochowski M., Wiewiórowska-Domagalska A., Prawo UE o uboju zwierząt i jego polska implementacja: kolizje interesów i ich rozwiązanie (cz. II), „Europejski Przegląd Sądowy", grudzień 2013.

Mozgawa M., Prawnokarna ochrona zwierząt, Lublin 2001.

Müllerova H., Niebezpieczne zwierzęta: ochrona zwierząt i ochrona cztowieka przed nimi $w$ czeskiej regulacji prawnej, „Ochrona Środowiska Prawo i Polityka" 2011, Nr 1.

Müllerova H., Ochrona środowiska a Europejski Trybunał Praw Człowie$k a$, „Ochrona Środowiska. Prawo i Polityka” 2010, Nr 1. 
Nazar M., Normatywna dereifikacja zwierzat - aspekty cywilnoprawne, [w:] Prawna ochrona zwierzat, pod red. M. Mozgawy, Lublin 2002.

Pietrzykowski T., Etyczne problemy prawa. zarys wykładu, Katowice 2005.

Radecki W., Ustawa o ochronie zwierząt. Komentarz, Warszawa 2012.

Radecki W., Ustawy: o ochronie zwierząt, o doświadczeniach na zwierzętach - z komentarzem, Warszawa 2007.

Radecki W., V. Stejskal, Uvod do pravni upravy ochrany prirody a peče o biologickou rozmanitost, Praha 2006 - artykut recenzyjny, „Biuletyn Parków Krajobrazowych Wielkopolski" 2007, z. 13.

Radecki W., V. Stejskal, Vyvojowe tendence pravni upravy ochrany prirody - artykut recenzyjny, „Biuletyn Parków Krajobrazowych Wielkopolski" 2013, z. 19.

Stelmasiak J., Komentarz do ustawy z dnia 21 sierpnia 1997 r. o ochronie zwierzat, [w:] Kompetencje po reformie administracji publicznej, pod red. Z. Niewiadomskiego, Warszawa 2000.

\section{Kontakt e-mail:}

daria.danecka@gmail.com 